\title{
HUBUNGAN KEKUATAN OTOT LENGAN DENGAN KETEPATAN SERVIS BAWAH OLAHRAGA BOLA VOLI PADA SISWA KELAS VIII SMPN 3 WATES KABUPATEN KEDIRI
}

\author{
Karjito \\ SMP Negeri 3 Wates - Kediri \\ karjitowates@gmail.com
}

\begin{abstract}
The study is done for the muscular strength of relations arm with the accuracy of serve down in the game of volleyball to their students the son of the eighth grade SMPN 3 Wates. The study aims to know is there a relationship with the power of the arm musclas to their students the son of the eighth grade to do under the accuracy of serve in the game of sport branch volleyball. A problem in the formulation of this research is the relationship has the power of the arm muscles with the accuracy of serve down in the game of the branch of sport volleyball on students the son of a class of eight SMPN 3 Wates. The research is research the is non experimentation and the use of the study or kolerasional product-moment correlation. The subject of this research is the son of a class of 30 students, data collection techniques used in tests. Based on the above data analysis hes been obtained that $r$ count of more large table to $r$. and with $r$ count of $0,966 r$ table with 0,361 is significant leve of 5\%. With the hypothesis said there is a muscular power arm with the accuracy of serve down in a game of volleyball sports can be accepted, can be concluded so that a significant relation exists between the power of the arm muscles with the accuracy of serve down in game of volleyball in sports the son of a class of eight students SMPN 3 Wates.
\end{abstract}

Key Words: The power of the arm muscles, the accuracy of serve under.

\section{PENDAHULUAN}

Pendidikan jasmani di sekolah merupakan dasar yang baik bagi perkembangan olahraga di dalam maupun di luar sekolah. Tujuan pendidikan jasmani adalah membentuk anak menjadi manusia yang sempurna, peranan dari pendidikan jasmani itu sendiri untuk merangsang pertumbuahan, perkembangan, meningkatkan kemampuan gerak dan ketrampilan berbagai macam permainan dan olahraga (Depdiknas, 2003:1) Oleh karana itu, Pendidikan jasmani sangat penting bagi masyarakat.
Salah satu tujuan dari pendidikan jasmani di lembaga-lembaga pendidikan diantaranya ialah untuk meningkatkan kemampuan siswa dalam aktivitas jasmani yang diaplikasikan melalui cabang-cabang olahraga yang sudah memasyarakat di lingkungan lembaga pendidikan atau sekolah bersangkutan. Pada kenyataannya masyarakat banyak mengharapkan peningkatan kemampuan peserta didik terutama dalam cabang olahraga. Olaharaga membentuk manusia sehat jasmani dan rohani serta mempuyai watak disiplin 
dan pada akhirnya membentuk manusia berkualitas.

Dari sekian banyak bahan pendidikan jasmani terdapat cabang olahraga yang sangat digemari masyarakat yaitu bola voli. Tidak jarang lagi kita meliat olahraga bola voli pada masyarakat, dari anak-anak sampai orang dewasa dan tidak memandang laki-laki, perempuan olahraga bola voli bisa dimainkan oleh siapapun, oleh karena itu peningkatan permainan bola voli pada siswa di sekolah harus ditingkatkan melihat tuntutan masyarakat yang sangat besar.

Permainan bola voli dimainkan oleh 2 (dua) tim dimana dalam satu tim terdapat 6 (enam) pemanin yang dipisahkan oleh sebuah net. Bola voli adalah salah satu permainan dalam cabang olahraga permanian bola besar. Tujuan dari permainan bola voli sendiri adalah melawatkan bola di atas net agar dapat jatuh menyentuh lantai pada lapangan lawan dan untuk mencega usaha yang sama dari lawan. Bola diyatakan dalam permaian setelah bola dipukul oleh pelaku sevis melewati atas net ke daerah lawan (PP.PBVSI, 2005:1).Untuk dapat bermain bola voli yang baik pemanin harus menguasai teknik-teknik permainan bola voli. Teknik-teknik dasar bermaina bola voli yang harus dikuasai adalah servis, pasing, smash, blok. Dalam permaian bola voli servis adalah awalan dalam pemainan atau sentuhan pertama dengan bola.

Servis yang baik sangat mempengaruhi seluruh jalanya pertandingan. Ada 3 (tiga) macam servis dalam permaian bola voli ada servis bawah, servis atas dan jump servis. Servis bawah merupakan servis yang paling popular dan paling sering dipakai terutama pada pertandinganpertandingan tingkat rendah atau pemula. Hal itu dimungkinkan karena servis bawah memang merupakan yang paling mudah terutama bagi para pemula. Dengan servis ini mereka dapat menguasai atau mengontrol bola dengan lebih teliti.

Oleh sebab itu, berdasarkan karakteristik tersebut, penulis beranggapan bahwa dengan melakukan servis bawah yang tepat kunci awal dalam peyerangan untuk mendapatkan poin dan meyulitkan lawan untuk menyerang, maka seorang pemain bola voli harus latihan teknik servis dan juga melatih teknik-teknik bermain bola voli lain untuk menjadi pemain yang berprestasi.

Berdasarkan pemaparan latar belakang diatas peneliti tertarik untuk meneliti tentang bola voli yang berjudul: hubungan kekuatan otot lengan dengan ketepatan servis bawah permainan olahraga bola voli pada siswa kelas VIII SMPN 3 Wates".

Dengan demikian, penelitian ini bertujuan untuk mengetahui informasi 
data secara empiris tentang ada tidaknya hubungan kekuatan otot lengan dengan ketepatan servis bawah dalam permainan bolavoli dan mengetahui ada atau tidaknya hubungan yang berarti dalam hubungan kekuatan otot lengan dengan ketepatan servis bawah dalam olahraga bola voli.

\section{METODE PENELITIAN}

Metode penelitian dibutuhkan dalam suatu pembahasan persoalan yang bersifat ilmiah, dengan metode penelitian ini akan memperoleh satu cara untuk mencapai kebenaran. Menurut Suharsimi (2006:149), "Metode adalah menentukan cara bagaimana dapat memperoleh data mengenai variabel-variabel tersebut".

Penelitian yaitu mengamati suatu objek yang akan diteliti dan kemudian dari hasil penelitian tersebut dapat ditarik kesimpulan. Di dalam penelitian itu sendiri ada dua hal yang perlu dipahami, yaitu metode dan penelitian. Metode adalah suatu cara yang diatur secara sistematis dan berfikir baik-baik untuk mendapatkan atau mencapai suatu tujuan, sedangkan penelitian adalah pemeriksaan atau penelitian secara teliti pada obyek tertentu. Jadi yang dimaksud dengan metode penelitian adalah suatu cara yang ditempuh untuk mencapai suatu tujuan dalam penelitian.Dalam penelitian ini memberikan perlakuan secara khusus pada sampel, sehingga peneliti ini bersifat non-eksperimen dan menggunakan studi korelasional korelasi product-moment (Arikunto, 1998).

Dalam penelitian ini hanya menggunakan dua variabel antara kekuatan otot lengan dan ketepatan servis bawah dalam olahraga bola voli pada siswa kelas VIII SMPN 3 Wates. Adapun desain penelitianya adalah sebagai berikut.

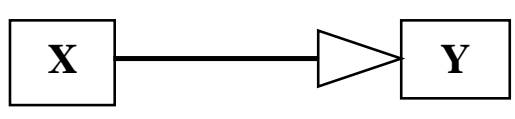

\section{Keterangan:}

Variabel $X=$ kekuatan otot lengan

Variabel $Y=$ ketepatan servis bawah

Adapun langkah-langkah yang dilakukan dalam penelitian ini adalah sebagai berikut

a. Mengumpulkan data dengan menggunakan tes kekuatan otot lengan

b. Mengumpulkan data dengan menggunakan tes ketepatan servis bawah

c. Menarik suatu simpulan dari tes kekuatan otot lengan dan ketepatan servis bawah

Menurut Suharsimi arikunto (1998:115) “Populasi adalah keseluruhan subjek penelitian. Apabila seorang ingin meneliti semua elemen yang ada dalam wilayah penelititan, maka penelitiannya merupakan penelitian populasi. Menurut Anderson (1975), Populasi adalah himpunan atau kumpulan 
seluruh elemen yang memiliki satu atau lebih sifat yang menjadi enteres peneliti.

Suharsimi arikunto (1998:115) menyatakan "Populasi adalah keseluruhan subjek penelitian. Apabila seorang ingin meneliti semua elemen yang ada dalam wilayah penelititan, maka penelitiannya merupakan penelitian populasi. Menurut Anderson (1975), Populasi adalah himpunan atau kumpulan seluruh elemen yang memiliki satu atau lebih sifat yang menjadi enteres peneliti.

Populasi sebagai obyek yang diteliti pada dasarnya harus mempunyai kualitas dari ciri-ciri yang yang ditetapkan baik atau tidak, maupun banyaknya manusia maupun gejala yang ada. Dalam penelitian ini populasi yang digunakan adalah siswa putra kelas VIII SMPN 3 Wates

Berkaitan dengan sampel, maka suharsimi arikunto (1998:117) dalam bukunya menyatakan "sampel adalah sebagian atau wakil populasi".

\section{Sedangkan}

penentuan pengambilan sampel yang digunakan dalam penelitian ini, seperti yang dijelaskanoleh Arikunto (1998:120) sebagai berikut: “Untuk sekadar ancangancang maka apabila subjeknya kurang dari 100, lebih baik diambil semua sehingga penelitianya merupakan penelitian populasi. Selanjutnya jika jumlah subjeknya besar dapat diambil antara $10-15 \%$, atau $20-25 \% "$.
Cara pengambilan sampel menggunakan sistem simple random sampling. Merupakan teknik sampling yang memberikan peluang yang sama bagi individu yang menjadi anggota populasi untuk di pilih menjadi anggota sampel. Teknik random bisa di lakukan dengan cara undian/dengan angka random. Sebagai contoh, jika kita memiliki populasi siswa sebesar 200, sementara itu kita ingin mengambil sampel sebanyak 40 siswa, maka kita bisa memilih 40 siswa dari 200 siswa yang ada. Apabila dilakukan secara undian maka nama/bisa juga dengan kode dari 200 siswa tersebut dimasukkan ke dalam suatu tempat untuk kemudian di kocok. Setelah di kocok-kocok baru kemudian di keluarkan/diambil satu demi satu hingga diperoleh sampel sebanyak 40 siswa (Maksum, 2012:55)

Untuk Memperoleh data yang diperlukan di pergunakan alat tes dan pengukuran. Menurut Nurhasan (1986: 16) dikatakan. Tes dan pengukuran merupakan bagian yang integral dari suatu proses evaluasi kegiatan belajar mengajar dalam proses pengumpulan data.Kegiatan pengumpulan data ini adalah merupakan suatu proses pengukuran. Dalam penelitian ini ada dua tes yang akan digunakan untuk mendapatkan data dari siswa yang pertama adalah tes kekuatan otot lengan dengan menggunakan alat hand dynamometer, dan yang kedua adalah tes 
ketepatan servis. Analisis data $\sum \mathrm{y}=$ Jumlah skor dari variabel terikat merupakan suatu cara yang diperoleh $\left(\sum \mathrm{x}\right)^{2}=$ Jumlah kuadrat dari variabel dari tes dan pengumpulan data. Dalam bebas suatu penelitian, data yang diperoleh harus ilmiah, reliabel, akurat, tepat, relevan, dan mengena pada apa yang akan menjadi tujuan dari penelitian ini.

Peneliti menggunakan metode $\left(\sum y\right)^{2}=$ Jumlah kuadrat dari variabel terikat

Xy = Jumlah perkalian setiap kasus variabel

analisis data yang sesuai dengan judul artikel di atas. Hal ini untuk menganalisa data yang diperoleh selama mengadakan penelitian di SMPN 3 Wates.

Selanjutnya untuk menarik suatu kesimpulan diperlukan analisis data tersebut, guna membuktikan hipotesis itu benar atau salah, sehingga dapat ditarik suatu ringkasan.Analisis data dapat dilakukan dengan dua cara yakni analisa statistik dan analisa non statistik. Dalam hal ini peneliti menggunakan metode analisa statistik maka objektif dari hasil penelitian akan terjamin. Analisis statistik memberikan efisiensi dan efektivitas kerja karena dapat membuat data yang lebih ringkas bentuknya. Teknik statistik yang dipergunakan adalah dengan rumus korelasi product moment.

$$
r x y=\frac{N \cdot \sum X Y-\sum X \cdot \sum Y}{\sqrt{\left(\left(N \cdot \sum X^{2}-\left(\sum X\right)^{2}\right)\left(N \cdot \sum Y^{2}-\left(\sum Y\right)^{2}\right)\right\}}}
$$

Keterangan :

$$
\begin{array}{ll}
\text { rxy } & =\text { Korelasi antara variabel } \\
& \text { bebasdenganvariabelterikat } \\
\mathrm{N} & =\text { Jumlah kasus (subjek) } \\
\sum \mathrm{xy} & =\text { Jumlah skor dari variabel bebas }
\end{array}
$$

\section{HASIL PENELITIAN}

Berdasarkan hasil analisis data, dapat diketahui bahwa hasil $r$ hitung lebih besar dari $r$ tabeldengan $r$ hitung sebesar 0,966 dan $r$ tabel dengan taraf signifikan 5\% adalah 0,361. Jadi hipotesis bahwa apakah ada hubungan antara kekuatan otot lengan dengan ketepatan servis bawah dapat diterima. Hasil $r$ hitung lebih besar dari $r$ tabel

\section{PEMBAHASAN}

Dengan data di atas selanjutnya dikonsultasikan dengan $r$ tabel. Menunjukkan bahwa hubungan antara kekuatan otot lengan dengan ketepatan servis bawahdalam permainan cabang olahraga bola voli dimana dapat diketahui bahwa hasil $r$ hitung sebesar 0,966 dan $r$ tabel dengan taraf signifikan $5 \%$ adalah 0,361. Jadi hipotesis dapat diterima karena $r$ hitung lebih besar dari pada $\mathrm{r}$ tabel (rhitung 0,966 > r tabel 0,361), dengan demikian Ho ditolak dan H1 diterima artinya ada hubungan yang signifikan antara kekuatan otot lengan dengan ketepatan servis bawah dalam 
olahraga bola voli pada siswa (putra) kelas VIII SMPN 3 Wates.

\section{SIMPULAN}

Dari uraian latar belakang di atas, maka dapat dianjurkan suatu rumusan masalah yaitu: Apakah ada hubungan kekuatan otot lengan dengan ketepatan servis bawah dalam permainan cabang olahraga bola voli pada siswa putra kelasVIII SMPN 3 Wates, maka diperoleh simpulan bahwaada hubungan kekuatan otot lengan dengan ketepatan servisbawah dalam permainan cabang olahrag bola voli pada siswa putra kelas VIII SMPN 3 Wates.

Hal ini dapat dilihat dari hasil analisis data yang menunjukkan bahwa diperoleh perhitungan sebesar 0,966 sehingga ada hubungan antara kekuatan otot lengan dengan ketepatan servis atas pada permainan bola voli.

\section{DAFTAR PUSTAKA}

Arikunto, suharsimi. 1998. Ptosedur penelitian: Rineka cipta.

Ahmadi, Nuril. 2007. Panduan Olahraga Bola Voli. Era Pustaka Utama: Surakarta.

Bompa. 1994. Theory and Methodology Or Training. Jakarta: Departemen Pendidikan dan Kebudayaan.

Barbara L. Viera \& Bonnine Jill Ferguson. 2004. BOLA VOLI. PT. Rajagrafindo.
Engkos Kosasih. 1985. Olahraga Teknik dan Program Latihan. Jakarta: PT Enka Parahyangan.

M. Yunus. 1992. Olahraga pilihan bola voli. Jakarta: Depdikbud Dirjendikti proyek pembinaan Tenaga kependidikan.

Muhyi. 2009. Meningkatkan Kebugaran Jasmani Melalui Permainan dan Olahraga Bola Voli. Jakarta: Grasindo

Maksum, Ali. 2012. Metodologi Penelitian Dalam Olahraga. Unesa University. Nurhasan, 1986. Buku materi Pokok Tes dan Pengukuran. Bandung: Departemen pendidikan dan kebudayaan, Universitas terbuka.

Suharno. H.P. 1985. Dasar-dasar Permainan Bola Voli. IKIP Yogyakarta: Andi Offset. 